\section{COVID-19 PANDEMIC AND CONSUIMER RIGHTS PROTECTION}

KEY WORDS: COVID-19 disease, Pandemic, Consumer rights and Consumer Protection.

\section{Bharat Patil*}

\section{Nerita Patil}

Matoshri Bayabai Shripatrao Kadam, Kanya Mahavidyalaya, Kadegaon, Sangli, (MS), India. *Corresponding Author

The present research paper is focused on the protection of consumer rights during COVID-19 pandemic. Consumer is the king of market but locked at home due to COVID-19 pandemic. The restrictions on consumer has hampered all economic activities of the country. Nationwide lockdown in India has created challenges before the consumer. In this attempt is made to understand how the rights of the consume is effected during the lockdown. The study will guide and suggest plan of action to maintain and protect the consumer rights. It is researched based article concerned to better understand the normal rights of the consumer. The study is undertaken during lockdown period to understand the consumer protection system. If consumer is satisfied it helps to maintain the law and order in the country and develop the cooperative attitude among the society. Attempt is made to simplify topic for better administration of the pandemic situation arisen due to COVID-19. This article will help to create awareness among society towards consumer protection. Satisfied consumer assists to develop hands in hands for efficient administration and fight the pandemic situation. The role of government in protecting the consumer rights during lockdown period is remarkable. Attempts were made to measure the experience of the students related to unfair and restricted trade practices. Every consumer is expecting to enjoy their rights but during pandemic it is more realistic to renounce their rights to combat coronavirus.

\section{INTRODUCTION}

Role of consumer during lockdown period is remarkable because maintaining social distancing, staying at home and obey the instructions given by the government. Government imposes restrictions on the consumer to avoid public places by the consumers to combat COVID-19. Consumer are required to renounce their rights to some extent to fights against the novel coronavirus. It helps to develop the nationalism and patriotism in the society. In lockdown period social distancing is only one temporary and short term solution to combat of novel coronavirus. Lockdown is one of the preventative measures. Consumer should strictly obey the rules of social distancing and avoid the public places. Scientists are engaged in the development of vaccine of novel coronavirus which will be a game changer. Success starts with today's intelligent scientists. They are working day and night to achieve the target of developing vaccine. Hospital facilities are making enrich to equip to pandemic situation. Government is working with cooperation with entrepreneurs, religious institutions to fight against the virus. Government adopted integrated incident management system to overcome the pandemic situation. Consumer Protection Act, 1986 amended in 2015 and 2019 to provide assured safeguards to the consumer. Consumer Protection Councils includes, The Central Consumer Protection Council, The State Consumer Protection Councils, The District Consumer Protection Council. Consumer Dispute Redressal Agencies consists District Forum, State Commission and National Commission is set up to protect consumer from defects in goods and deficiencies in services. United Nations Conference on Trade and Development (UNCTAD) issued guidelines for consumer protection to all members. It describes the rights and responsibilities of the consumer. Government of India acting as a care taker of the consumer and Indian constitution strongly support for consumer protection. The ultimate efforts of all these is the protection of consumer rights. Now a day's consumer is becoming more conscious about their rights. Consumer rights includes the right to safety, right to be heard, right to satisfy basic needs, right to get information of goods and services, right to consumer education, right to redress, enjoy healthy market environment, right to choose and right to fair and honest dealing. Every consumer is expecting to enjoy these rights.

\section{Review of Literature}

K. Tejbati Devi $(2016)^{1}$, concluded that consumer rights are human rights though may be in an indirect manner.
Researcher expect to recognition is necessary for better and wider protection of the consumer interest. Also added that the time has come for full fledge recognition of consumer rights as human rights so that there cannot be an escapism clause from the violation of consumer rights. It is suggested that awareness along with the interaction programs should be conducted for the better understanding as well as better protection of the consumer interest. It is recommended that the international institutions as well as the international community should contribute and work together for the proper development of consumer rights as human rights.

Koteshwar Burna $(2017)^{2}$, observed that all customers are purchasing products, branded and unbranded and majority of the customers are observing defects in the quality. Most of the customers are rejecting the product and complaint to the shop keepers and more than $54 \%$ of the customers are aware about the Consumer Protection Act and $92 \%$ of the consumer are not getting the response within the specified time. Further added that present system of Consumer Protection Act is satisfactory but in future this act should be amended to provide better service towards consumer protection.

Rajanikanth $(2017)^{3}$ he observed that there was a rise in the awareness of consumer rights and utilization of provisions in the CPA. There was a growth in the amount of self-regulation in public and private sectors. He suggests that consumer was slowly losing their interest in the redress mechanism as the remedies were insufficient and the legal machinery is ineffective. CPA is proving a relief to those who are aware of it, but there is a need to strengthen the agencies under it. It also shows that the Consumer Protection Act 1986 needs some amendments and clarifications about the terms and functioning of redress agencies.

Kanipakam, S. (2017) ${ }^{4}$, was concluded that consumer should get value of their hard earn money in the form of quality goods and better services. It is true that modern technological developments have made a great impact on the quality, availability and safety of goods and services. According to his findings consumer are still victims of unfair and restrictive trade practices adopted by trader or manufacturer. Further suggested that speccial task force group of experts on consumer protection law and policy has been established to monitor the implementation of the guidelines, provide a forum for consultations, produce research and studies and provide technical assistance. 
Singh (2014) ${ }^{5}$, (Bery, Biswas and Aggarwal), they concluded that public awareness about CPA and medical negligence has increased in the last decade. They added that awareness about CPA and medical negligence among the medical as well as surgical specialists is unsatisfactory and suggested that doctors must update their understanding on Consumer Protection Act and medical negligence to reduce of risk of litigation and to be legally safe.

Suresh Patidar ${ }^{6}$, (2013), concluded that Consumer Protection Act, 1986 was enacted for the protection of the interest of consumer as per the guidelines of United Nations. He added that there is a need to improve in the implementation of CPA and also to incorporate some of provisions, which can protect the interest of consumer fully in coming years.

\section{Methodology}

Due to COVID-19 it is not possible to issue questionnaire physically to the students. So questionnaire is prepared by using Google Form. A structured questionnaire was communicated with the students through WhatsApp. The researchers used an explanatory research design to understand consumer protection and awareness under COVID-19 situation. The present study is based on the awareness of the Consumer Protection Act, 1986 among the students. Research methodology is developed for better research design, sampling and hypothesis is formulated. Results and discussion helps to draw conclusions and suggestions.

\subsection{MATERIAL AND METHODS}

Convenience sampling technique was used for the selection of samples. The present study was conducted on 73 students of commerce faculty of Matoshri Bayabai Shripatrao Kadam Kanya Mahavidyalaya, Kadegaon, Tal. -Kadegaon, Dist. Sangli. Before circulating questionnaire, the researchers explained the objectives of the data collection to the respondents. A Google Form questionnaire having 07 questions related to various aspects of consumer protection and awareness is prepared.

\subsection{AIMS AND OBJECTIVES}

1. To examine the nature of consumer protection and an awareness among the students of Matoshri Bayabai Shripatrao Kadam Kanya Mahavidyalaya, Kadegaon.

2. To study an awareness about Consumer Protection Act, 1986 among the students.

3. To understand the challenges faced by the students while purchasing goods during lockdown period.

4. To find about the role of government for consumer protection and awareness created during lockdown period.

5. To point out unfair and restrictive trade practices adopted by trader or manufacturer during lockdown period.

6. To suggest the remedies for the protection of consumer rights during pandemic situation.

\subsection{Hypothesis of the study}

$\mathrm{H}_{0}=$ COVID-19 effects on the consumer rights.

$\mathrm{H}_{1}=$ COVID- 19 not effects on the consumer rights.

\subsection{Research Design}

\subsubsection{Scope of the Study}

The study was covered to understand the consumer protection and level of awareness among the students. The scope of the study confined with only Consumer Protection Act, 1986. Researchers attempted to understand the legal awareness among the students. It also covers the scope to what efforts were taken by the government and its various agencies for consumer protection during lockdown period. Present study is only related to the pandemic situation arisen due to COVID-19 and various measures taken for the protection of consumer rights. The research was carried during the period of country wide lockdown.

\subsubsection{Limitations of the Study}

i. The researchers only attempted to analyse the consumer protection among the students of Matoshri Bayabai Shripatrao Kadam Kanya Mahavidyalaya, Kadegaon during the nationwide lockdown period.

ii. Correlated literature on consumer protection and COVID-19 pandemic situation were not available for present study.

iii. Researchers mostly relies on the questionnaires filled by the students through Google Forms and not applied direct interview technique and personal visits to the students due to lockdown in India.

iv. Present study related to consumer protection during COVID-19 pandemic situation. Present study is only confined to Consumer Protection Act, 1986. Other legal regime in India for the protection of consumer rights was not considered.

v. The study time covers only the lockdown period so there may be a chance for sampling error in data collection.

\subsubsection{Source of Data}

Data collection in the lockdown period is a challenging work. Especially from the students who are in examination stress due to lockdown. The researchers used following sources of data collection.

\subsubsection{Primary Data}

The following techniques were used to collect primary data during lockdown period.

\section{i.Discussions}

Discussion were made with students about lockdown situation and consumer protection and consumer awareness. A request is made to the students to fill the Google Forms sent through WhatsApp for data collection.

\section{ii. Observation}

Researchers observe the lockdown period and its effect on consumer protection and governments special efforts for the protection of consumer rights.

\section{iii. Questionnaire}

For data collection a questionnaire is prepared in Google Form and circulated through WhatsApp to the students for getting response.

\subsubsection{Secondary Data}

Secondary data is collected with the help of following sources.

i. Government reports and circulations.

ii. Newspapers, periodicals and research articles.

iii. Web sites related to COVID-19 and consumer protection.

\subsubsection{Expected contribution of the study}

i. Rights of the consumer are universal rights. Present study will help for aggressive administration of the consumer protection during pandemic situation due to COVID-19.

ii. The study will help for policy formulators to for efficient administration of consumer protection during pandemic period.

\section{RESULTS AND DISCUSSION}

Consumerism strengthens the spirit of consumer protection in the country. Consumer is the king of the market. According to the need of the consumer, production and distribution activates are carried out in the economy. But king of market is locked at home due to COVID-19 disease and its effects on all the sectors of the economy. Lockdown situation break the commitment as a consumer is the king of the market. For the protection of the consumer rights in India various legislative provisions were made. The purpose of legislations is providing the safeguard to the interest of the consumer from the malpractices in the trade. Government of India declared lockdown from $25^{\text {th }}$ March, 2020 for maintaining social 
distancing to overcome pandemic situation. Social distancing is essential in the market place. Unrest is increasing due to misunderstanding and rumours among the society. Government departments are ready to face the challenge created by novel coronavirus (COVID-19). Government is trying to maintain well coordination between the various departments to handle the situation. Inter-state transport of people and non-essential goods was totally banned in the first phase (1.0) and second phase (2.0) of lockdown to control the spreading the disease. Testing kit of COVID-19 disease was ordered by the Government from other countries to fulfil the needs. Shortage of testing kit, its price and timely availability is challenge before the health department. Personal Protective Equipment ((PPE) at early stage of pandemic were not sufficient. As the number of patients increasing in India creates the burden over the administrative department. History of patient is more important for the case management. Suspected persons are kept in isolation ward and swab is sent to the laboratories for testing. Government is engaged to make the arrangement of hospital beds to equip the increasing number of patients. Shortage of ventilators as compared to increasing patients caused due to increasing the tension of hospital management. Public were not taking proper precautions in the market place. Consumer should renounce their rights to fights against the novel coronavirus. Restrictions on transportation of cargo are removed in 2.0 and 3.0 phase of lockdown period. MNREGA work provided to the workers who are jobless due to lockdown to maintain the buying capacity of essential goods of the consumer. From the starting period of lockdown, government did not impose any restrictions on agricultural activities. Agriculture provide job opportunities to rural poor farm workers. Government attempts to maintain the rights of the consumer during lockdown period. But government imposes restrictions on consumer rights during lockdown period as a part of preventative measures. District administration circulates the rules and regulations to manage the crowd in the market. During phase 1.0 and 2.0 of lockdown government imposed restrictions on online marketing of non-essential goods. In phase 3.0 and 4.0 online marketing of non-essential goods are allowed with some restrictions. Selected sample students aware the knowledge of consumer rights through the syllabus which covers The Consumer Protection Act, 1986. Attempt was made to understand specific knowledge from the selected samples. Questionnaire is prepared in Google Forms and sent to the respondents. Total 73 respondents were given response to the questionnaire. The analysis of the data collected through Google Form is as follows.

Table No 1 Appropriate Present System of Consumer Protection

\begin{tabular}{|c|c|c|}
\hline Response & No of respondents & Percentage \\
\hline Agree & 66 & 90.41 \\
\hline Disagree & 07 & 9.59 \\
\hline Total & $\mathbf{7 3}$ & $\mathbf{1 0 0}$ \\
\hline
\end{tabular}

Source:Primary data

Chart No. 1

Appropriate Present System of Consumer Protection

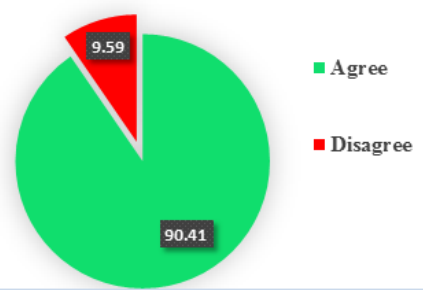

Chart No. 1 shows the approach of the of the respondents towards present system of consumer protection is appropriate or not. 90.41 percent respondents agree with the statement. 9.59 respondent's express views to make additional changes in law for the safeguard of consumer interest.
Table No 2 Consumer Rights Protected in Lockdown Period

\begin{tabular}{|c|c|c|}
\hline Response & No of respondents & Percentage \\
\hline Yes & 58 & 79.45 \\
\hline No & 15 & 20.55 \\
\hline Total & $\mathbf{7 3}$ & $\mathbf{1 0 0}$ \\
\hline
\end{tabular}

Source:Primary data

Chart-2

Consumer's Rights Protected During Lockdown Period

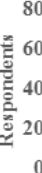
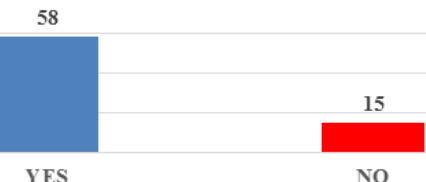

During the research it was found that 58 (79.45\%) respondents are positive towards the consumer rights protected during the nationwide lockdown. Government has taken appropriate steps to protect the interest of consumer during lockdown period. Only 15 respondents out of 73 had experienced that their rights were hampered during lockdown period.

Table No 3 Role of Government for Protecting Consumer Rights

\begin{tabular}{|c|c|c|}
\hline Response & No of respondents & Percentage \\
\hline Strongly Agree & 73 & 100 \\
\hline Disagree & 00 & 00 \\
\hline Total & $\mathbf{7 3}$ & $\mathbf{1 0 0}$ \\
\hline
\end{tabular}

Source:Primary data

It reveals from the above table that almost all the respondents strongly agree with role of government towards taking appropriate initiatives for protecting consumer rights during the lockdown period. It is the duty of every nation to be conscious to protect the rights of consumer and create awareness among them.

Table No 4 Restricted Trade Practices Experienced in Lockdown Period

\begin{tabular}{|c|c|c|}
\hline Response & No of respondents & Percentage \\
\hline Yes & 36 & 49.32 \\
\hline No & 37 & 50.68 \\
\hline Total & $\mathbf{7 3}$ & $\mathbf{1 0 0}$ \\
\hline
\end{tabular}

Source: Primary data

Out of total 73 respondents 36 respondents have experienced unfair and restricted trade practices applied by the traders in lockdown period. Traders applied deceptive, fraudulent methods to obtain business. Traders charged extra price of goods and services and do not maintain the manufacturing standards of goods. Traders control the normal flow of supplies and taken advantages of consumer fear of lockdown. 37 respondents did not experience the unfair and restricted trade practices during lockdown period.

Table No 5 Rights of Consumer Protected in Online Marketing

\begin{tabular}{|c|c|c|}
\hline Response & No of respondents & Percentage \\
\hline Satisfied & 40 & 54.79 \\
\hline Partially Satisfied & 21 & 28.77 \\
\hline Dissatisfied & 12 & 16.44 \\
\hline Total & $\mathbf{7 3}$ & $\mathbf{1 0 0}$ \\
\hline
\end{tabular}

Source:Primary data

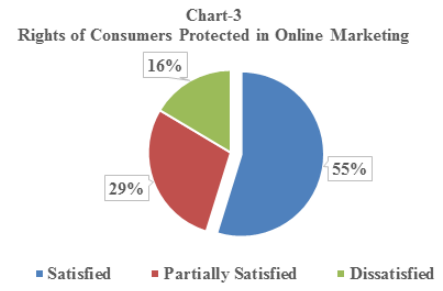

|www.worldwidejournals.com $\mid$ 
During the study it is found that 54.79 percent respondents are satisfied with rights of consumer that were protected in online marketing. 28.77 percent partially satisfied with the service of online marketing. 16.44 percent respondents were dissatisfied towards the service of online marketing.

Table No 6 Compromising Attitude Towards Products/ Services During Lockdown Period

\begin{tabular}{|c|c|c|}
\hline Response & No of respondents & Percentage \\
\hline Yes & 65 & 89.04 \\
\hline No & 08 & 10.96 \\
\hline Total & $\mathbf{7 3}$ & $\mathbf{1 0 0}$ \\
\hline
\end{tabular}

Source:Primary data

The respondents are classified according to compromising attitude towards products/services during lockdown period. 89.04 percent respondents admitted that they compromised alternative products and services during lockdown period due to shortage of specific goods. 10.96 percent respondents were not compromising towards goods and services.

\section{Table No 7 Complain to Consumer Forum}

\begin{tabular}{|c|c|c|}
\hline Response & No of respondents & Percentage \\
\hline Yes & 00 & 00 \\
\hline No & 73 & 100 \\
\hline Total & $\mathbf{7 3}$ & $\mathbf{1 0 0}$ \\
\hline
\end{tabular}

Source: Primary data

From the above table it is concluded that none of the respondents ever complained to the consumer forum. It is a good sign that respondents do not reach to the consumer forum.

\section{Findings, Suggestions and Conclusions \\ 5.1 Findings}

1. From the study it was found that the Central and State governments had taken appropriate steps to safeguard the rights of the consumer.

2. The researchers observed that government initiatives towards maintaining social distancing in the market places for the sake of consumer.

3. Researchers had found that the role of district administration in maintaining marketing environment during lockdown period to purchase of essential goods is remarkable. They issue guidelines for traders and consumer for better administration of market of essential goods.

4. From the study it was found that supply of agricultural goods was not sufficiently available to the consumer during lockdown period. Farmers were unable to supply their agricultural goods smoothly. Restrictions on transportation created a gap between farmers and consumer.

5. During research it was found that administrative authority attempted to control the unfair and restricted trade practices in the interest of consumer in the lockdown period.

6. It was also found that the government has imposed restrictions on consumer movement in the market to break the chain of COVID-19 disease.

7. From the study it is observed that government had taken steps to create consumer awareness through social media.

\subsection{Suggestions}

1. Researchers suggests that during pandemic situation government should frame a policy which strongly tighten the economic relationship of producers, supplies and consumer for the economic development of the country.

2. From the study it is suggested that unfair and restrictive trade practices are applied by the traders. Strict action is required for infringement of law related to consumer protection during lockdown period.

3. From the researcher's point of view, it is suggested that there should be economic package to the industry and agriculture sector during this economic crisis. It helps to develop the healthy market environment.

4. Researchers suggest to strengthen consumerisms spirit. It will be definitely promoting the protection of consumer rights in the country.

5. It is strongly recommended that during the pandemic situation consumer should cooperate with administrative authorities to break the chain of spreading the COVID-19 disease.

6. There should be strict implication of rules framed for purchasing of essential goods during lockdown period.

7. Researchers give suggestions to create awareness among the consumer by the government, social media and NGOs.

8. It is recommended that better coordination between the different departments of the government was required to normalise the market conditions.

9. Supply chain management work efficiently during the lockdown period is essential to maintain stock of essential goods in the market otherwise it creates unrest among the consumer.

10. It is recommended that police department should not behave violently to human and consumer rights by using unusual and humiliating punishment to the consumer while enforcing the lockdown. The consumer also should cooperate with the administration and obey the rules for effective implementation of the lockdown.

\subsection{CONCLUSIONS}

To combat COVID-19 pandemic, the role of the consumer in market is remarkable. The crowd of consumer in market place increases the tension of the administration. Administration is balancing the rights of consumers and controlling consumer in the market. The results of the study assist for efficient administration of consumer rights during the pandemic situation. The restrictions imposed by the government on consumer is appropriate to handle the pandemic situation and beneficial to maintain the social distancing in the market. The research guides to the scholars for further study in consumer rights and pandemic situation. The researchers concluded that the present system of consumer protection is required more compressive to handle the unfair and restricted trade practices. More than ninety percent respondents agree with the present system is appropriate for the protection of consumer rights. Eighty percent respondents admitted that during the lockdown period consumer rights are protected. All the respondents strongly admitted that government had taken appropriate steps to protect the rights of the consumer during lockdown period.

\section{REFERENCES}

1. Devi, K.T., (2016), "Legal Regime for the Consumer Protection and its Human Rights Perspective", International Journal of Law and Legal Jurisprudence Studies, Volume 3 (3), pp.316-331.

2. Koteshwar, B., (2017), "Awareness of Consumer Protection Act- A Study of Consumer Domestic Appliances", International Journal of Academic Research in Social Sciences \& Humanities, Vol.3, (2), pp. 18-22.

3. Rajanikanth, M., (2017), "A Study on Evolution of Consumer Protection Act in India - CPA1986", International Journal of Application or Innovation in Engineering \& Management, Volume 6, (4),pp. 133-138.

4. Kanipakam, S. (2017), "Consumer Protection in India - A Special Reference to the Right to Safety", International Journal of Advanced Research, 5(6), pp. 719723.

5. Singh (2014), Bery, Biswas and Aggarwal, "Awareness about Consumer Protection Act and Medical Negligence among Private and Government Medical College \& Hospital Faculty Members"Journal of Indian Acad Forensic Medicine,Vol.36,(2),pp. 150-155.

6. Patidar, S. (2013), "The Consumer Protection Act, 1986 of India- 25 Years of Enactment: A Critical Study", Pacific Business Review International, Volume 6, (6), pp.1-5. 